\title{
Studies on Patterns of the Binding of Androgen with Serum Protein by the Method of Centrifugal Ultrafiltration (II)
} Binding of Dehydroepiandrosterone Sodium Sulfate with Bovine Serum Protein

\section{Hisao ISHIKAWA}

Department of Obstetrics and Gynecology, School of Medicine, Kanazawa University

(Director : Prof. Fumio Akasu)

Studies were carried out for the elucidation of the binding of dehydroepiandrosterone sodium sulfate (DHA-S) with bovine serum protein by the method of centrifugal ultrafiltration. In order to examine the stoichiometric relation among the concentrations of DHA-S, protein, and DHA-S protein complex, twoseries of experiments were performed.

1) With the constant concentration of protein $(3.4 \mathrm{gm} / \mathrm{dl})$, the concentration of DHA-S was varied, i.e., $80,160,240,320$, and $400 \mu \mathrm{g} / \mathrm{cc}$.

2) With the constant concentration of DHA-S $(400 \mu \mathrm{g} / \mathrm{cc})$ the concentration of bovine serum protein was varied, i.e., 1.7, 3.4, 5.1 and $6.1 \mathrm{gm} / \mathrm{dl}$.

These solutions were equilibrated with $5 \% \mathrm{CO}_{2}$ in air for 20 to 30 minutes at $37^{\circ} \mathrm{C}$ ( $\mathrm{pH} 7.4$ ) and $5 \mathrm{cc}$ of the solution was centrifuged for 15 minutes at 3000 r.p.m., the radius of rotation being $15 \mathrm{~cm}$. lcc of ultrafiltrate was acid hydrolyzed and extracted with ether. The colorimetric determination of DHA was carried out according to the method of Zimmermann.

The results were as follows:

1) The concentration of diffusible DHA-S in ultrafiltrate was 13.7, 17.0, 31.5, 44.6, $62.8 \mu \mathrm{g} / \mathrm{gmH}_{\lrcorner} \mathrm{O}$ when the original solution contained DHA-S at the concentration of 80 , $160,240,320$, and $400 \mu \mathrm{g} / \mathrm{cc}$ respectively with the constant concentration of protein.

2) In this series of experiments the ratio of the amount of the bound DHA-S to the total amount of DHA-S added was 83.5, 89.8, 87.1, 86.6, and 84.9\% and there seems to be no significant difference among these values. The amount of bound DHA-S per unit amount of protein was 2.1, 4.4, 6.5, 8.5, and $10.2 \mathrm{mg} / \mathrm{gm}$ protein respectively.

3) In the second series of experiments where the protein concentration in the original solution was changed keeping the total concentration of DHA-S constant, the concentration of diffusible DHA-S in the ultrafiltrate varied in reciprocal fashion. To the protein concentration of $1.7,3.4,5.1$, and $6.1 \mathrm{gm} / \mathrm{dl}$ the corresponding values of diffusible DHA-S obtained were 111.3, 46.9, 17.5, and $12.2 \mu \mathrm{g} / \mathrm{gmH}_{2} \mathrm{O}$.

4) The ratio of the bound steroid to the total amount added increased as the protein concentration increased, the corresponding values being 72.1, 88.3, 95.6, and 97.0\%. The amount of the bound DHA-S was $16.0,9.9,7.1$, and $6.0 \mathrm{mg} / \mathrm{gm}$ protein.

5) These results were analyzed according to the equations of Freundlich and of Klotz. The data seem more suitable for the equation of Freundlich so that the binding of DHA-S with serum protein seems to be due to physical adsorption.

(pp. 457〜456) 


\title{
遠心限外濾過法による Androgen の
}

\section{血清蛋白結合に関する研究}

特に, Dehydroepiandrosterone sodium sulfate のウシ血清蛋白との 結合について

\author{
金沢大学医学部産科婦人科学教室 （指導 赤須文男教授） \\ 石川 久 夫
}

(昭和38年 2 月 13 日受付)

第 1 章 緒言

著者は前報で, 遠心限外滤過法を応用するてとによつて, 血清中に溶解している Dehydroepiandrosterone sodium sulfate (以下 DHA.S と略す) を極めて生理的な条件下で，容易に蛋白結合分画と非結合分画と に分離し得るととを記述した1).

Migeon and Plager 2) (1954) が Dehydroepiandrosterone（以下 DHA そ略）を人血清から分離して以 来，DHA を中心とした血中 17-Ketosteroids（以下 17-KS と略）の濃度および状態についてはかなり多 くの報告がなされている. Clayton et al. ${ }^{3)} は$ Alumina を用いた Column Chromatography によつて, 4 人の健康男子から集めた $950 \mathrm{cc}$ の血漿より DHA と Androsterone（以下 Androst. と略）を分離し，そ の血中 $17-\mathrm{KS}$ 総值に対する分画比をそれぞれ $65 \% ， 11 \%$ と報じている，また，遊離の型をとつた血中 17 KS はとるに足ら微量であり，グルクロン酸結合型 17-KS も全 17-KS の12\%に過ぎず，他の大部分は 硫酸結合型であろうと考えた。同じ頃，Migeon and Plager ${ }^{4}$ は加水分解を加觉ない血漿，および， $\beta$ Glucuronidase で水解した血漿から 17-KS を抽出するのに失敗したが，酸水解後の血漿について Paperchromatography を用いて DHA と Androst. を分画・定量し, 血漿 100cc中の DHA 量は 40.5 $\mu \mathrm{g}$ で Androst. 量の約 2 倍に相当すると述べている. 血中の DHA 量については, その後も, Oertel and Eik-Nes $^{5)}$ は $57.5 \mu \mathrm{g} / \mathrm{dl}$, Saier et al. ${ }^{6)}$ は加水分解に Burstein and Lieberman の Solvolysis を用いて, 男子では $38.2 \mu \mathrm{g} / \mathrm{dl}$, 女子では $50.5 \mu \mathrm{g} / \mathrm{dl}$ としている。近年, Baulieu $\left.{ }^{7}\right)$ は正常人血漿と回復期患者の $\mathrm{ACTH}$ 投与後の血漿について, 加水分解を加えることなしに硫酸と結合した 17-KS の存在を証明し，そ れをさらに DHA, Androst., Etiocholanolone の硫酸結合型に分画した，彼によれば，硫酸結合型 DHA，

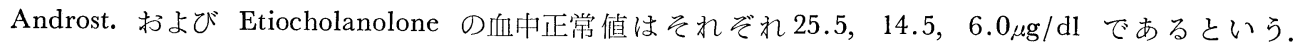
Conrad et al. ${ }^{8}$ も血漿中の DHA sulfate と Androst. sulfate を直接に, 即ち, 水解操作を加えないで 定量して，血漿 100cc 中の含有量をそれぞれ男子で155〜298 $\mu \mathrm{g}, 29 \sim 92 \mu \mathrm{g}$, 女子では 85〜166 $\mu \mathrm{g}, 15 \sim 45 \mu \mathrm{g}$ と報告している，また，乙の測定法では血漿中の遊離型およびグルクロン酸結合型の 17-KS を検出し得な かつたと述べている。

以上の報告にみるように，血中 17-KS の主要分画は DHA と Androst., 殊に DHA であり，しかも， てれらは大部分が硫酸と結合して存在しているととが知られる。遊離型およびグルクロン酸結合型をとつた 血中 17-KS の存在については, Cohn et al. ${ }^{9}$, Clayton et al. ${ }^{3}$, Kellie and Smith ${ }^{10)} ら の$ 報告があるが, 硫 酸結合型に比べて極めて微量と考光られる.

このように DHA sulfate は血中 17-KS の中で最も主要な分画であるが，その生理学的意義は全く不明と いつても過言でなく，それを解明する端緒ともいうべき血清蛋白との結合に関する研究もまた極めて少ない，

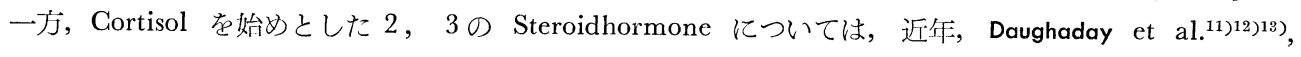


Slunwhite and Sandberg(14)15), Mills et al., ${ }^{16)}$ Booth et al. ${ }^{17)}$ 等によつて血清蛋白との結合に関する優れた 研究がなされており，DHA sulfate についてもその研究・報告が待たれている現状である.

著者は血中における DHA sulfate の動態の一端を知る目的で，遠心限外濾過法を用いて生理的状態下の $\mathrm{DHA} \cdot \mathrm{S}$ と血清蛋白との結合率を測定し，DHA sulfate の生理学的意義解明の一端に寄与しようとした.

\section{第 2 章 実験材料および実験方法}

\section{第 1 節 実験材料}

血清としてはウシ血清を使用した，屠殺後直ちに放血される血液を数時間放置した後，遠心分離して血清 を得た。なお，血清蛋白の定量には Biuret 法 $^{18)}$ を使用した。

\section{第 2 節 遠心限外濾過装置}

遠心限外濾過装置については前報 ${ }^{1)}$ 亿既報したからこてでは省略し，また，限外濾膜も前報と同じくコロ ジオン濃度 $4 \%$, 乾燥時間 3 分, 厚さ $0.3 \mathrm{~mm}$ の和紙コロジオン膜を用いた.

\section{第 3 節 温度の調節}

本実験では，生理的条件のもとで $\mathrm{DHA} \cdot \mathrm{S}$ と血清蛋白間の結合を観察するため，常に温度を $37.5^{\circ} \mathrm{C}$ に調 節した。試料を入れた遠心限外濾過装置は， $37.5^{\circ} \mathrm{C}$ 亿温度を調節した恒温箱内の遠心器に30分間静置された 後, 遠心器の蓋を開けたまま遠心にかけられた。 このようにして著者は，還心操作中の温度を $37.5 \pm 0.5^{\circ} \mathrm{C}$ に保つととができた。

\section{第 4 節 PH の調節}

上述の方法で得られたウシ血清は $\mathrm{CO}_{2}$ の脱出によつて $\mathrm{pH}$ がかなりアルカリ側に傾いているため，生 理的条件下で実験を行なうには，脱出した $\mathrm{CO}_{2}$ を補つて $\mathrm{pCO}, \mathrm{pH}$ を正常值に戾すてとが必要である. このために，試料を $5 \%$ CO $\mathrm{CO}_{2}$ を含む空気と約 30 分間平衡させ，さらに，平衡後 $\mathrm{CO}_{2}$ が脱出するのを防 ぐように限外濾過管内の試料に流動パラフィンを約 $3 \mathrm{~cm}$ の厚さに重ねた。 このととにより遠心中の水分蒸 散をも同時に防ぐてとができる，また，限外滤過管を入れる気密の遠心管のガスパイプから， $5 \% \mathrm{CO}_{2}$ を 含んだ空気を送り込んでてれを遠心管内の空気とおきかえた，以上の操作により，試料の $\mathrm{pH}$ を $7.3 \sim 7.5$ に調節することができる。 なお， $\mathrm{pH}$ の測定は微量がラス電極法 ${ }^{19}$ により $37.5^{\circ} \mathrm{C}$ に測定した.

\section{第 5 節 実験方法の大要}

各種濃度の DHA·S 水溶液をウシ血清と任意の比率で混合し，てれを遠心して濾液中の DHA・S 量から 血清中の拡散性 DHA·S 量を算出した.

最初に血清中の $\mathrm{DHA} \cdot \mathrm{S}$ 濃度が蛋白結合に及ぼす影響をみるために，Table 1 の如き試料を調製した。即 ち， $0.08 \%$ の $\mathrm{DHA} \cdot \mathrm{S}$ 水溶液を順次蒸溜水で稀釈し，乙れに等量のウシ血清を混じて DHA·S の終末濃 度を $80 ， 160 ， 240 ， 320 ， 400 \mu \mathrm{g} / \mathrm{cc}$ とした. なお，blank としてウシ血清と蒸溜水を1：1 亿混合したも のを同時に限外濾過にかけた。 乙れら試料の各10ccを既述の方法で $\mathrm{pH}$ を $7.3 \sim 7.5$ に補正後, 限外濾過管

Table 1. Group of samples

\begin{tabular}{|c|c|c|c|c|c|}
\hline Group & $\begin{array}{c}0.08 \% \\
\mathrm{DHA} \cdot \mathrm{S} \text { Sol. }\end{array}$ & Aq. distil. & Bovine serum & $\begin{array}{l}\text { Final conc. } \\
\text { of } \mathrm{DHA} \cdot \mathrm{S}\end{array}$ & $\begin{array}{l}\text { Final conc. } \\
\text { of serum protein }\end{array}$ \\
\hline I & 1 vol. & 4 vol. & 5 vol. & $80 \mu \mathrm{g} / \mathrm{cc}$ & $3.4 \mathrm{gm} / \mathrm{dl}$ \\
\hline II & $2 "$ & $31 "$ & " & $160 "$ & " \\
\hline III & 311 & $2 \quad 11$ & " & $240 "$ & " \\
\hline IV & $4 \prime$ & 111 & " & $320 "$ & " \\
\hline $\mathrm{V}$ & $5 "$ & 0 & " & $400 "$ & " \\
\hline$\underset{\text { (Blanki }}{\mathrm{VI}}$ & 0 & 5 vol. & " & $\fallingdotseq 0$ & " \\
\hline
\end{tabular}


の上節に入れて流動パラフィンを重ね, 気密の遠心管に収容した。遠心は $37.5^{\circ} \mathrm{C}$ 怛温箱中に30分間静置 後, 回転半径 $15 \mathrm{~cm}, 3000$ r.p.m. で15分間施行した。遠心後, 下節のガラス容器内に貯溜した限外滤液の一 部を $20 \%$ スルホサリチル酸中に滴下して蛋白の存在しないととを確かめ, 次の方法で濾液の DHA・S 濃度 を測定した，滤液 $1 \mathrm{cc}$ 蒸溜水を加えて10ccとし，乙れに $10 \mathrm{vol} . \%$ の濃硫酸を添加して $100^{\circ} \mathrm{C} て ゙ 15$ 分間水

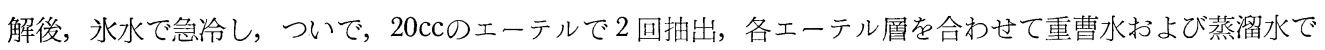
中性になるまで洗涤した。洗條後のエーテル層を蒸発乾固し, その残渣について Zimmermann 反応を行 なつた。比色は分光光電光度計（日立 EPU 2 型）を使用して波長 $460,520,580 \mathrm{~m} \mu$ での吸光度を測定し, Allen の補正式を用いて補正した。同時に, 既知量 $(25,50 \mu \mathrm{g})$ の DHA.S 局様操作で水解・抽出・発 色して, てれから被検滤液中の $\mathrm{DHA} \cdot \mathrm{S}$ 量を計算した。遠心後の濾液が $1 \mathrm{cc}$ 亿達しない時には, 同群試料 の滤液を数個のガラス容器から集めてその $1 \mathrm{cc}$ を定量に使用した。なお，DHA・S を添加せずにウシ血清の みを滤過した時の滤液中の DHA 量 (blank) は，本測定法で常に0とみなすととができた.

ついで, 血清蛋白濃度と限外滤過性 DHA・S 濃度との関係を知る目的で, ウシ血清に $1 / 10$ 容の $4 \mathrm{mg} / \mathrm{cc}$ $\mathrm{DHA} \cdot \mathrm{S}$ 水溶液を混じててれを原液とし，400 $\mathrm{g} / \mathrm{cc} \mathrm{DHA} \cdot \mathrm{S}$ 水溶液で稀釈して種々の蛋白濃度の溶液を作 つた。即ち, DHA·S 混合血清原液と $400 \mu \mathrm{g} / \mathrm{cc} \mathrm{DHA} \cdot \mathrm{S}$ 水溶液とをそれぞれ $2.5: 6.5,5: 4,7.5$ : 1.5 の比で混合した。 このようにすると各溶液の血清蛋白終末濃度はそれぞれ元の血清蛋白濃度の $25 \%, 50$ $\%, 75 \%, 90 \%$ (原液) となり, DHA·S 終末浱度は $400 \mu \mathrm{g} / \mathrm{cc}$ となる。 その後の操作および定量方法は上 述の場合と同様である.

試料は多量の蛋白質を含有しているために水分含有量はその限外滤液よりはるかに少ない, 従つて, 濾液 中の DHA.S 量から試料中の拡散性 DHA・S 濃度を推算する際には, それを溶媒単位容量当りに表わさず 飞単位水分量当りの量で表わす必要がある。一般に，血清の水分含有量は McLean and Hastings ${ }^{20}$ に従つ て次式から計算される。

$\mathrm{W}=99.0-0.75 \times \mathrm{P}$

$\mathrm{W}$ : 血清 $100 \mathrm{cc}$ 中の水分量 $(\mathrm{gm})$

$\mathrm{P}:$ 血清蛋白濃度 $(\mathrm{gm} / \mathrm{dl})$

著者も上の式を用いて血清中の水分含有量を計算し, 拡散性 DHA・S の濃度を水 $1 \mathrm{gm}$ 当りの量で表わし た. ただし血清中の水はすべて溶媒として作用する自由水とみなしてある.

\section{第 3 章 実 験 成 績}

血清蛋白濃度 $3.4 \mathrm{gm} / \mathrm{dl}, \mathrm{pH} 7.3 \sim 7.5$, 温度 $37.5^{\circ} \mathrm{C}$ の実験条件での血清中 DHA.S 濃度と拡散性 DHA •S 濃度との関係をみると, Fig. 1 亿示されるよう亿 DHA.S 終末濃度が80，160，240，320，400 $\mu \mathrm{g} / \mathrm{cc} の$ 時の拡散性 $\mathrm{DHA} \cdot \mathrm{S}$ 濃度は平均 $13.7 \pm 1.09,17.0 \pm 2.58,31.5 \pm 1.43,44.6 \pm 4.72,62.8 \pm 2.71 \mu \mathrm{g} / \mathrm{gmH}_{2} \mathrm{O}$ であつた。一方, DHA.S の非拡散性分画は蛋白飞結合している分画とみなされるが, 全 DHA·S 量に 対するその分画比即ち DHA.S の 血清蛋白結合率を求めると Fig. 2 の如く, DHA.S 濃度が 80, 160, $240 ， 320 ， 400 \mu \mathrm{g} / \mathrm{cc}$ ではそれぞれ $83.5 \pm 1.29,89.8 \pm 1.53,87.1 \pm 0.43,86.6 \pm 1.43,84.9 \pm 0.63 \%$ であ り，ほとんぞ一定であつた。また，蛋白 $1 \mathrm{gm}$ 当りの DHA·S 結合量を求めるとそれぞれ $2.1 \pm 0.01,4.4$ $\pm 0.09,6.5 \pm 0.06,8.5 \pm 0.15, \quad 10.2 \pm 0.34 \mathrm{mg}$ であり, Fig. 3 亿みられるように $80 \sim 400 \mu \mathrm{g} / \mathrm{cc}$ の範囲 では DHA·S の濃度が濃くなるにつれて直線的に増加している。 以上を総括して, 蛋白濃度 $3.4 \mathrm{gm} / \mathrm{dl}$, $\mathrm{pH} 7.3 \sim 7.5$, 温度 $37.5^{\circ} \mathrm{C}$ での DHA.S 濃度と血清蛋白結合の関係を Table 2 亿表示した.

血清蛋白濃度を变化させて，それが DHA・S の蛋白結合に及ぼす影響を DHA·S 終末濃度 $400 \mu \mathrm{g} / \mathrm{cc}$, pH7.3〜 7.5, 温度 $37.5^{\circ} \mathrm{C}$ の条件で観察した結果を Table 3 およびFig.4 , 5, 6 亿示した. まず，Fig.4 にみ られるように血清蛋白濐度が1.7，3.4，5.1，6.1 $\mathrm{gm} / \mathrm{dl}$ と增加するにつれて，拡散性 DHA·S 濃度は111.3 $\pm 3.69,46.9 \pm 2.61,17.5 \pm 2.78,12.2 \pm 0.64 \mu \mathrm{g} / \mathrm{gm} \mathrm{H}_{2} \mathrm{O}$ と減少している。一方, 拡散性 DHA.S 濃度と 反対関係の DHA.S 血清蛋白結合率は, 血清蛋白濃度が $1.7 \mathrm{gm} / \mathrm{dl}$ の時には平均 $72.1 \pm 0.92 \%, 3.4 \mathrm{gm} / \mathrm{dl}$ 
Fig. 1. Effect of conc. of added DHA $\cdot S$ on conc. of ultrafiltrable DHA $\cdot S$

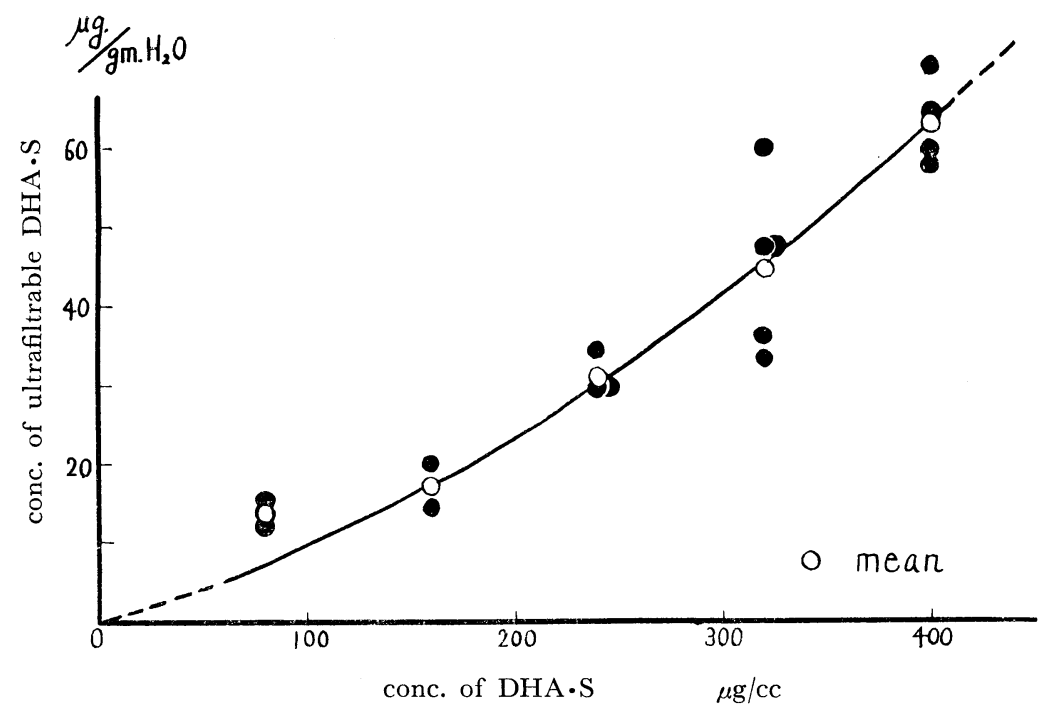

Fig. 2. Effect of conc. of added DHA.S on percentage of protein-bound $\mathrm{DHA} \cdot \mathrm{S}$ to total DHA.S

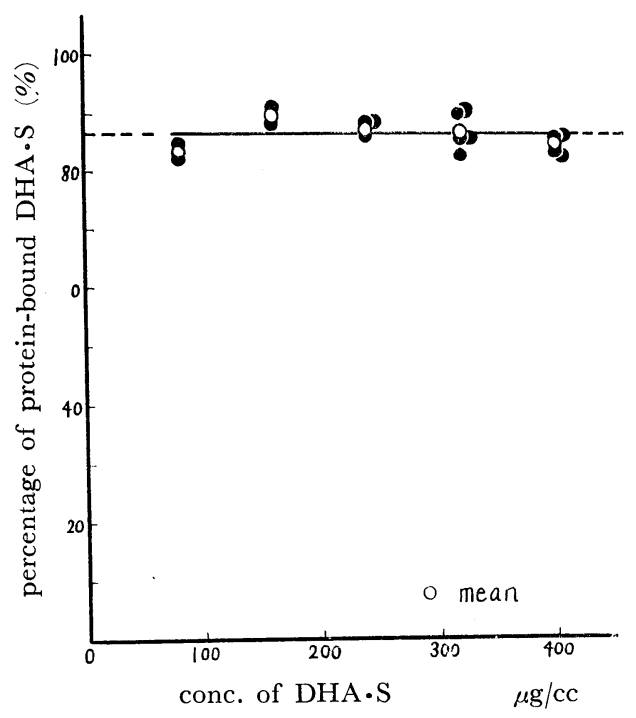

Fig. 3. Effect of conc. of added DHA.S on amount of protein-bound DHA.S per $\operatorname{lgm}$ serum protein

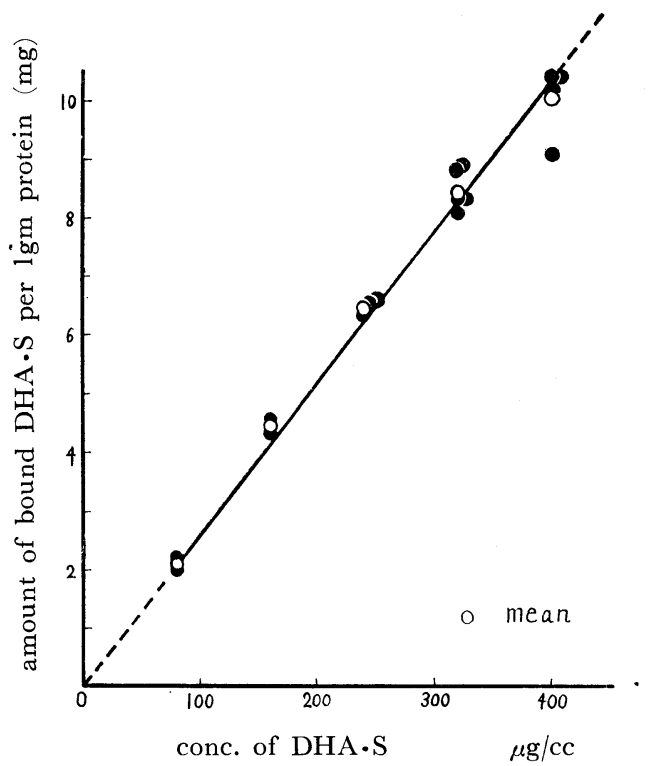

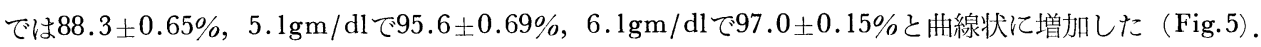
また，蛋白 $1 \mathrm{gm}$ 当りに結合している DHA·S 量を算出すると Fig. 6 のように，それぞれ $16.0 \pm 0.21$, $9.9 \pm 0.08,7.1 \pm 0.04,6.0 \mathrm{mg}$ であつた. 
Table 2. Effect of concentration of added DHA.S on DHA.S-protein binding

\begin{tabular}{|c|c|c|c|c|}
\hline $\begin{array}{l}\text { Final conc. } \\
\text { of } \mathrm{DHA} \cdot \mathrm{S}\end{array}$ & $\begin{array}{l}\text { Conc. of ultra- } \\
\text { filtrable DHA.S }\end{array}$ & $\begin{array}{l}\% \text { of ultra- } \\
\text { filtrable DHA.S }\end{array}$ & $\begin{array}{l}\% \text { of protein- } \\
\text { bound DHA.S }\end{array}$ & $\begin{array}{l}\text { Amount of bound } \\
\text { DHA.S per } 1 \mathrm{gm} \\
\text { protein }\end{array}$ \\
\hline $80 \mu \mathrm{g} / \mathrm{cc}$ & $\begin{array}{l}12.6 \mu \mathrm{g} / \mathrm{gm} \mathrm{H}_{2} \mathrm{O} \\
14.8\end{array}$ & $\begin{array}{l}15.2 \% \\
17.8\end{array}$ & $\begin{array}{l}84.8 \% \\
82.2\end{array}$ & $\begin{array}{l}2.1 \mathrm{mg} / \mathrm{gm} \\
2.0\end{array}$ \\
\hline Mean & $13.7 \pm 1.09$ & $16.5 \pm 1.29$ & $83.5 \pm 1.29$ & $2.1 \pm 0.01$ \\
\hline 160 & $\begin{array}{l}14.4 \\
19.5\end{array}$ & $\begin{array}{r}8.7 \\
11.8\end{array}$ & $\begin{array}{l}91.3 \\
88.2\end{array}$ & $\begin{array}{l}4.5 \\
4.3\end{array}$ \\
\hline Mean & $17.0 \pm 2.58$ & $10.3 \pm 1.53$ & $89.8 \pm 1.53$ & $4.4 \pm 0.09$ \\
\hline 240 & $\begin{array}{l}34.4 \\
30.1 \\
30.1\end{array}$ & $\begin{array}{l}13.8 \\
12.5 \\
12.5\end{array}$ & $\begin{array}{l}86.2 \\
87.5 \\
87.5\end{array}$ & $\begin{array}{l}6.4 \\
6.5 \\
6.5\end{array}$ \\
\hline Mean & $31.5 \pm 1.43$ & $12.9 \pm 0.43$ & $87.1 \pm 0.43$ & $6.5 \pm 0.06$ \\
\hline Fiducial limits* & $25.4 \sim 37.7$ & $11.1 \sim 14.8$ & $85.2 \sim 88.9$ & $6.2 \sim 6.7$ \\
\hline 320 & $\begin{array}{l}47.5 \\
59.5 \\
47.4 \\
33.2 \\
35.6\end{array}$ & $\begin{array}{l}14.3 \\
17.9 \\
14.3 \\
10.0 \\
10.7 \\
\end{array}$ & $\begin{array}{l}85.7 \\
82.1 \\
85.7 \\
90.0 \\
89.3\end{array}$ & $\begin{array}{l}8.4 \\
8.1 \\
8.4 \\
8.9 \\
8.8\end{array}$ \\
\hline Mean & $44.6 \pm 4.72$ & $13.4 \pm 1.43$ & $86.6 \pm 1.43$ & $8.5 \pm 0.15$ \\
\hline Fiducial limits & $31.5 \sim 57.7$ & $9.5 \sim 17.4$ & $82.6 \sim 90.5$ & $8.1 \sim 8.9$ \\
\hline 400 & $\begin{array}{l}70.3 \\
63.2 \\
59.2 \\
58.4\end{array}$ & $\begin{array}{l}16.9 \\
15.2 \\
14.3 \\
14.1 \\
\end{array}$ & $\begin{array}{l}83.1 \\
84.8 \\
85.7 \\
85.9\end{array}$ & $\begin{array}{r}9.2 \\
10.4 \\
10.6 \\
10.6\end{array}$ \\
\hline Mean & $62.8 \pm 2.71$ & $15.1 \pm 0.63$ & $84.9 \pm 0.63$ & $10.2 \pm 0.34$ \\
\hline Fiducial limits & $54.2 \sim 71.4$ & $13.1 \sim 17.1$ & $82.9 \sim 86.9$ & $9.1 \sim 11.3$ \\
\hline
\end{tabular}

* degree of confidence 0.95

Table 3. Effect of concentration of serum protein on DHA.S-protein binding

\begin{tabular}{c|c|c|c|c}
\hline $\begin{array}{c}\text { Final conc. } \\
\text { of serum protein }\end{array}$ & $\begin{array}{c}\text { Conc. of ultra- } \\
\text { filtrable DHA.S }\end{array}$ & $\begin{array}{c}\% \text { of ultra- } \\
\text { filtrable DHA.S }\end{array}$ & $\begin{array}{c}\% \text { of protein- } \\
\text { bound DHA.S }\end{array}$ & $\begin{array}{c}\text { Amount of bound } \\
\text { DHA.S per lgm } \\
\text { protein }\end{array}$ \\
\hline \hline & $105.3 \mu \mathrm{g} / \mathrm{gm} \mathrm{H}_{2} \mathrm{O}$ & $26.3 \%$ & $73.7 \%$ & $16.4 \mathrm{mg} / \mathrm{gm}$ \\
& 96.4 & 24.1 & 75.9 & 16.8 \\
& 116.5 & 29.1 & 70.9 & 15.7 \\
$1.7 \mathrm{gm} / \mathrm{dl}$ & 114.0 & 28.5 & 71.5 & 15.8 \\
& 113.3 & 28.3 & 71.3 & 15.9 \\
& 122.0 & 30.3 & 69.5 & 15.4
\end{tabular}




\begin{tabular}{|c|c|c|c|c|}
\hline Mean & $111.3 \pm 3.69$ & $27.8 \pm 0.92$ & $72.1 \pm 0.92$ & $16.0 \pm 0.21$ \\
\hline Fiducial limits* & $101.8 \sim 120.7$ & $24.4 \sim 30.2$ & $69.8 \sim 74.5$ & $15.5 \sim 16.5$ \\
\hline 3.4 & $\begin{array}{l}56.5 \\
47.8 \\
46.8 \\
50.1 \\
41.6 \\
38.4\end{array}$ & $\begin{array}{r}14.1 \\
11.9 \\
11.7 \\
12.5 \\
10.4 \\
9.6\end{array}$ & $\begin{array}{l}85.9 \\
88.1 \\
88.3 \\
87.5 \\
89.6 \\
90.4\end{array}$ & $\begin{array}{r}9.6 \\
9.8 \\
9.8 \\
9.8 \\
10.0 \\
10.1\end{array}$ \\
\hline Mean & $46.9 \pm 2.61$ & $11.7 \pm 0.65$ & $88.3 \pm 0.65$ & $9.9 \pm 0.08$ \\
\hline Fiducial limits & $40.2 \sim 53.6$ & $10.0 \sim 13.4$ & $86.6 \sim 90.0$ & $9.6 \sim 10.1$ \\
\hline 5.1 & $\begin{array}{l}22.0 \\
12.2 \\
24.8 \\
11.5 \\
10.2 \\
24.4\end{array}$ & $\begin{array}{l}5.5 \\
3.1 \\
6.2 \\
2.9 \\
2.6 \\
6.1\end{array}$ & $\begin{array}{l}94.5 \\
96.9 \\
93.8 \\
97.1 \\
97.4 \\
93.9\end{array}$ & $\begin{array}{l}7.0 \\
7.2 \\
7.0 \\
7.2 \\
7.2 \\
7.0\end{array}$ \\
\hline Mean & $17.5 \pm 2.78$ & $4.4 \pm 0.69$ & $95.6 \pm 0.69$ & $7.1 \pm 0.04$ \\
\hline Fiducial limits & $10.4 \sim 24.7$ & $2.6 \sim 6.2$ & $93.8 \sim 97.4$ & $7.0 \sim 7.2$ \\
\hline 6.1 & $\begin{array}{l}11.5 \\
12.8\end{array}$ & $\begin{array}{l}2.9 \\
3.2\end{array}$ & $\begin{array}{l}97.1 \\
96.8 \\
\end{array}$ & $\begin{array}{l}6.0 \\
6.0\end{array}$ \\
\hline Mean & $12.2 \pm 0.64$ & $3.1 \pm 0.15$ & $97.0 \pm 0.15$ & 6.0 \\
\hline
\end{tabular}

* degree of confidence 0.95

\section{第 4 章 考按および結論}

DHA が他の Steroids と同様に，血漿蛋白または血清蛋白と結合しているととは周知の事実である。

Eik-Nes et al. ${ }^{21)}$ は DHA が水よりも5\%血清アルブミン溶液によく溶解するのを認めて, てれを DHA と血清アルブミンとの結合によつて説明した. Bongiovanni and Eberlein ${ }^{22)}$ 血漿中の DHA が蛋白に結 合しているのを確認して，その結合率は透析法抢よび硫酸アンモンを用いての塩析法で $100 \%$ ，水酸化再鉛， トリクロル酢酸による塩析および $\mathrm{pH} 3.0 ， 50^{\circ} \mathrm{C}$ で20分間放置による除蛋白操作で55〜93\%であつたと述べて いる. また，Oertel and Eik-Nes ${ }^{5)}$ は血中の DHA 定量に際して，血漿のエタノール分画とその残椬につい てそれぞれの DHA 量を測定し，全量の約 $25 \%$ を残渣中に見出した.

てのように，エタノール，硫酸アンモン，トリクロル酶酸等の除蛋白剤を使用した実験では，血漿または 血清の物理的，化学的な性質を変化させる可能性が極夺く，従つて，てのようにして求められた蛋白 との結合状態をそのまま生理的な状態とみなすてとには，討論の予地があろうと思われる，さらに，試料の 温度や $\mathrm{pH}$ 等の実験条件についても，それを生理的な值に調節するてとに充分な考慮がはらわれていない ように思われる．Steroids の蛋白結合に及ぼす温度と $\mathrm{pH}$ の影響については諸家の報告がある。. ${ }^{14) 16223) 2425)}$ Schellman et al..$^{23}$ は Testosterone とウシ血清アルブミンとの結合について $80.0^{\circ} \mathrm{C}, 25.0^{\circ} \mathrm{C}, 37.5^{\circ} \mathrm{C} の$ 温度で検討を加え，温度の上昇と共に結合量か增加するととを認めた。乙れに反して, Slaunwhite and Sandberg ${ }^{14)}$ は $\alpha$-グロブリンの Cortisol 結合能は温度の上昇につれて減少すると報じ， Chen et al. ${ }^{25}$ も

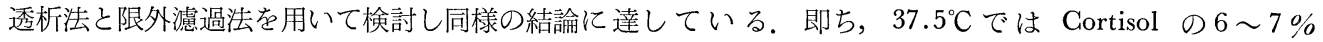


Fig. 4. Effect of conc. of serum protein on conc. of ultrafiltrable DHA.S

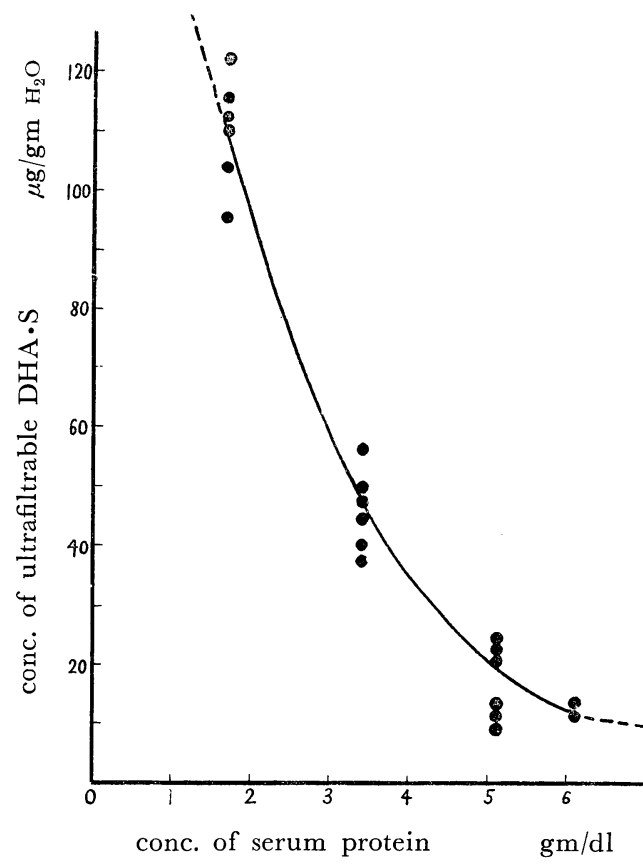

Fig. 6. Effect of conc. of serum protein on amount of protein-bound DHA.S per $1 \mathrm{gm}$ serum protein

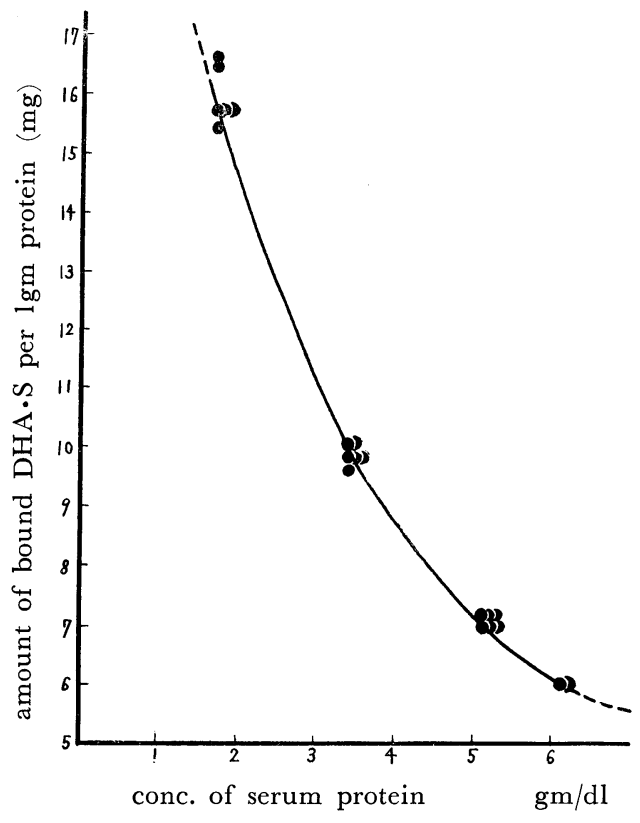

Fig. 5. Effect of conc. of serum protein on percentage of protein-bound DHA.S to total $\mathrm{DHA} \cdot \mathrm{S}$

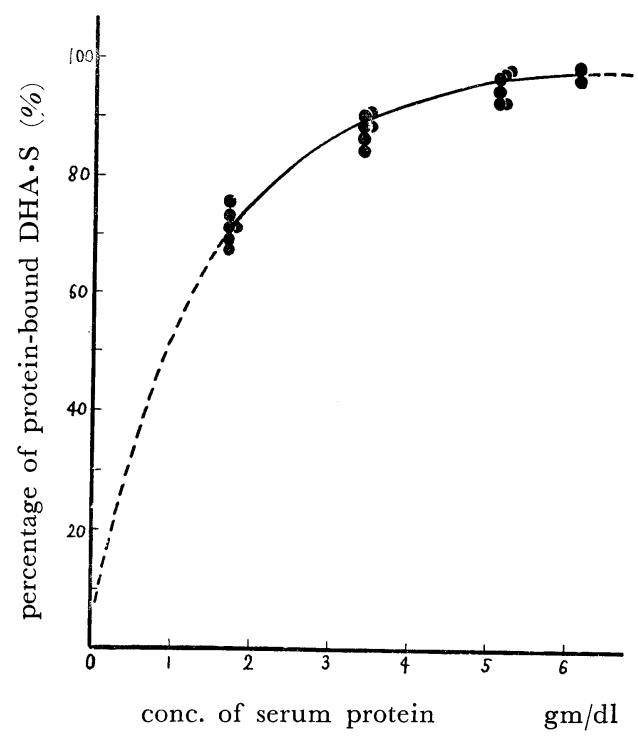

Fig. 7. Relation between $\log \frac{\mathrm{x}}{\mathrm{m}}$ and $\log \mathrm{C}$ (Freundlich' equation) $\mathrm{m}$ : conc. of serum protein $\left(\mathrm{mg} / \mathrm{kgH}_{\lrcorner} \mathrm{O}\right)$ $\mathrm{x}$ : conc. of protein-bound DHA $\cdot \mathrm{S}(\mathrm{mM})$ $\mathrm{kgH}_{2} \mathrm{O}$ )

c: conc. of ultrafiltrable DHA.S $(\mathrm{mM} / \mathrm{kg}$ $\mathrm{H}_{2} \mathrm{O}$ )

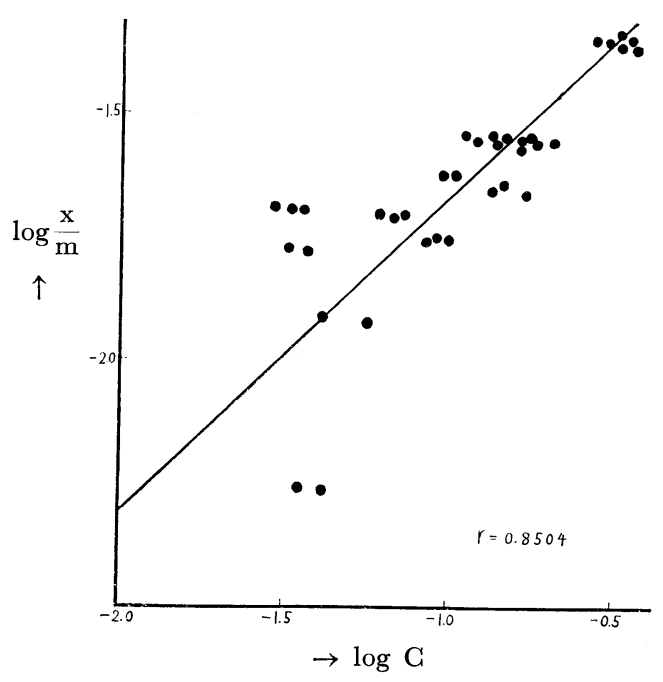




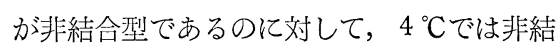
合型が $2 \%$ に減少したと述べている。なお， pH の影響については, Schellman et al.,23) Chen et al. ${ }^{25)}$ か Testosterone, Cortisol と 蛋白との結合は $\mathrm{pH}$ の上昇によつて増加の 傾向を有するのを認めている.

著者は血清の物理的・化学的性質を殆んど 損わず，しかも，極めて短い時間で容易に試 料を膠質分画と晶質分画とに分離し得る遠心 限外滤過法を用いて，DHA・S とウシ血清蛋 白との結合率を温度 $37.5^{\circ} \mathrm{C}, \mathrm{pH} 7.4$ 亿て測定 した.まず，DHA·S 終末濃度が $400 \mu \mathrm{g} / \mathrm{cc}$ と一定になるよう DHA.S 水溶液を血清と 任意の比率で混合し，数種の血清蛋白濃度に おける結合率を求めてその值から正常の血清 蛋白濃度での結合率を推算した（Fig. 5 参 照)。それによれば， $\mathrm{pH} 7.4$, 温度 $37.5^{\circ} \mathrm{C}$, 蛋白濃度 $6.8 \mathrm{gm} / \mathrm{dl}$ での $\mathrm{DHA} \cdot \mathrm{S}$ 蛋白結合率 は約 96〜97\% とみなされる。 DHA·S 等の
Fig. 8. Relation between $1 / \mathrm{r}$ and $1 /[\mathrm{I}]$ (Klotz' equation) $\mathrm{r}: \frac{\text { conc. of protein-bound DHA } \cdot \mathrm{S}(\mathrm{mM} / \mathrm{kgH}, \mathrm{O})}{\text { conc. of serum protein }\left(\mathrm{mM} / \mathrm{kgH}_{-} \mathrm{O}\right)}$ [I] : conc. of ultrafiltrable DHA.S $\left(\mathrm{mM} / \mathrm{kgH}_{4} \mathrm{O}\right)$

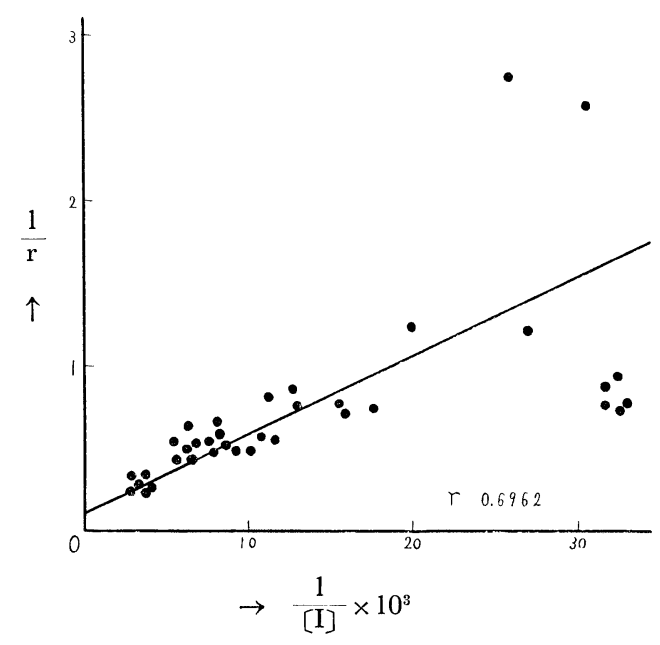

Steroids を血漿またはアルブミン溶液等に添加する際，そのまま試料に溶解させる方法は Steroids の水に 対する比較的低い溶解性から考えて, 完全に溶けずに試験管壁等に附着したまま残つたり, 蛋白と結合して いないのに限外滤膜を 透過しないで非拡散性分画に入れられる危険性がある，従つて，水に溶解させた Steroids 溶液を血清と任意の比率で混合して, 蛋白結合率と蛋白濃度との関係を求めた本法の方が, より正 確な実験成績を得るのに適していると考えられる。なお，DHA·S の蛋白結合に関する研究報告は全く見当 らないが，近年 (1961年)，Chen et al. ${ }^{25)}$ は著者と同様遠心限外濾過法を用いて遊離型の DHA と血漿蛋 白との結合率を測定し，著者の DHA・S 亿おける成績とほぼ一致した約92〜95\%の值を報告している.

血漿中 DHA·S 值は Baulieu") そよれば $25.5 \mu \mathrm{g} / \mathrm{dl}$, Conrad et al. $\left.{ }^{8}\right)$ とれば $80 \sim 300 \mu \mathrm{g} / \mathrm{dl}$ とされてお り，本実験で用いた試料の DHA·S 濃度はかなり高濃度であるが, DHA・S 終末濃度が $100 〜 400 \mu \mathrm{g} / \mathrm{cc} の$ 範 囲では85〜90\%と結合率はほぼ一定であることから（Fig. 2)，DHA·S の濃度による結合率の変動は殆ん ぞなく，生理的濃度においてもこの程度の結合率を示すものと推測される.

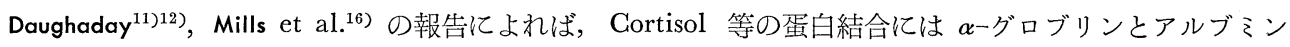
が関係しており，生理的な濃度では Cortisol 等に対して強い 親和性 をもつた $\boldsymbol{\alpha}$-グロブリンがまず結合に 参加し，その結合能が飽和に達すると大きな結合能力 (Capacity) を有するアルブミンが関与してくるてと が明らかとなつた. Chen et al. ${ }^{25}$ も も Cortisone とCortisol については同様の所見をみとめたが，DHAの 結合には $\alpha$ グロブリンは無関係でアルブミンがその主体をなしていると考えた. 同様, DHA·S と血清蛋 白との結合も主としてアルブミンによるものとすれば，アルブミンの大きな結合能力から考えて，本実駼で みられたように DHA·S の蛋白結合率が DHA·S の濃度に無関係でほぼ一定である事実も説明されよう。 また，種々の血清蛋白濃度における蛋白 $1 \mathrm{gm}$ 当りの DHA·S 結合量を求めてみると, 蛋白濃度が減少する につれて結合音は急速に増加しており，血清蛋白が極めて大きい結合能力を有しているてとを示している

(Fig. 6). 以上の事実から，血中の DHA·S との結合に関与している血清蛋白分画は主としてアルブミン であろうと推測される.

DHA·S を炲めとした各種 Steroidhormone と血漿蛋白または血清蛋白との結合の本態については，そ の生理学的意義と同様に不明の点が多くあり, 今後の解明が待たれている. 著者は今回の実験成績を Freu- 
ndlich の吸着式と Klotz の理論式 ${ }^{26)}$ とてはめて, DHA·S と血清蛋白との結合の本態について理論的考察 を試みた。

Freundlich の式は一般に $\frac{x}{m}=\mathrm{KG}^{-1}$ で表わされるが，乙れを変形すると次式となる.

$\log \frac{x}{m}=\frac{1}{n} \log \mathrm{C}+\log \mathrm{K}$

$\mathrm{m}:$ 血清蛋白濃度 $\left(\mathrm{mg} / \mathrm{kgH}_{2} \mathrm{O}\right)$

$\mathrm{x}$ : 非拡散性 DHA.S 濃度 $\left(\mathrm{mM} . / \mathrm{kgH}_{2} \mathrm{O}\right)$

$\mathrm{c}$ : 拢散性 $\mathrm{DHA} \cdot \mathrm{S}$ 濃度 $\left(\mathrm{mM} . / \mathrm{kgH}_{2} \mathrm{O}\right)$

$\mathrm{n}, \mathrm{k}$ : 恒数

著者の成績からそれぞれ $\log _{m}^{x}$ と $\log \mathrm{G}$ を求めて図示すると Fig. 7 のようになり，両者の間にはほぼ直 線関係がみとめられ，その相関係数は0.8504であつた，いいかえれば，著者の成績はかなりよくFreundlich の吸着式に適合するといえる。

一方, Klotz の理論式は $\frac{1}{r}=\underset{\mathrm{n}[\mathrm{I}]}{\mathrm{K}}+\frac{1}{\mathrm{n}}$ で表わされる.

$\mathrm{r}$ : 血清蛋白 1 分子当りの $\mathrm{DHA} \cdot \mathrm{S}$ 分子の結合数

[ I ] : 拡散性 DHA.S 濃度 $\left(\mathrm{mM} . / \mathrm{kg} \cdot \mathrm{H}_{2} \mathrm{O}\right)$

$\mathrm{n}$ : 血清蛋白 1 分子当りの $\mathrm{DHA} \cdot \mathrm{S}$ 分子の最大結合数

$\mathrm{k}$ : 恒数

血清蛋白の分子量を70,000として著者の成績より $1 / \mathrm{r}, 1 /[\mathrm{I}]$ を計算し，図示したのが Fig. 8 である. なお，1/r と1/[I]の相関係数は0.6962であつた. このように両者のかなり低い相関関係からみて，著 者の成績を Klotz の理論式にあてはめることは困難であり，むしろ Freundlich の吸着式に適合すると考 えるべきであろう．従つて，DHA·S と蛋白との結合は化学的反応というより，その大部分が物理的な吸着 によるものと思われる。

以上の実験成績から，著者は次の結論を得た。

1）遠心限外濾過法を用いてウシ血清蛋白（濃度 $6.8 \mathrm{gm} / \mathrm{dl}$ ) と $\mathrm{DHA} \cdot \mathrm{S}$ の結合率を $37.5^{\circ} \mathrm{C}, \mathrm{pH} 7.4$ にて 測定し，それが96〜97\%であることを確かめた.

2) DHA·S の濃度によつて，DHA・S の蛋白結合率は変化せずほぼ一定であつた. また，蛋白濃度が減 少するにつれて，単位蛋白量当りの DHA·S 結合量は急速に増加した. 以上から，DHA·S の結合に関与 する血清蛋白分画は，主として，大きな結合能力 (Gapacity) をもつたアルブミンと思われる.

3) DHA·S と血清蛋白との結合に関する著者の実験成績が，Freundlich の吸着式にかなりよくあては まることから，その結合は化学的な性質のものではなく主に物理的な吸着によるものと推測される.

(本論文要旨は第35回日本内分泌学会総会で発表した.)

擱筆に当り，御指導，御校閲を賜つた恩師赤須教授に心からの感謝を捧げると共に，貴重な御助言，御支 援を賜つた西田助教授に感謝します。

文献

1) 石川久夫：日本内分泌学会雑誌, $39: 439$ (1963). $\quad$ 2) MIGEON, C.J. and J.E. PLAGER : J. Biol. Chem., 209 : 767, (1954). $\quad$ 3) GLAYTON, G.W., A.M. BONGIOVANNI and G. PAPADATOS : J. Clin. Endocrinol. \& Metab., $15: 693$, (1955). 4) MIGEON, G.J. and J.E. PLAGER : J. Clin. Endocrinol. \& Metab., $15: 702$, (1955). 5) OERTEL, G.W. and K. EIKNES : J. Biol. Chem., 232 : 543, (1958). 6) SAIER, E.L., E. CAMPBELL, H.S. STRICKLER 第39巻 第 5 号 
and R.C. GRAUER : J. Clin. Endocrinol. \& Metab., 19 : 1162, (1959).

7) BAULIEU, E.E. : J. Glin. Endocrinol. \& Metab., $20: 900$, (1960).

8) GONRAD, S., V. MAHESH and W. HERRMANN : J. Clin. Invest., $40: 947$, (1961). 9) COHN, G.L., R.K. BONDY and C. GASTIGLIONE : J. Clin. Invest., $40: 400$, (1961). 10) KELLIE, A.E. and E.R. SMITH : Biochem. J., $66: 490$, (1957). 11) DAUGHADAY, W.H. : J. Clin.Invest., $37: 511$, (1958). 12) DAUGHADAY, W.H : J. Glin. Invest., $37: 519$, (1958). 13) DAUGHADAY, W.H., J. HOLLOSZY and I.K. MARIZ : J. Glin. Endocrinol. \& Metab., $21: 53$, (1961). 14) SLAUNWHITE, W.R. Jr. and A.A. SANDBERG : J. Clin. Invest., $38: 384$, (1959). 15) SANDBERG, A.A. and W.R. SLAUNWHITE, Jr. : J. Clin. Invest., $38: 1290$, (1959). 16) MILLS, I.H., H.P. SGHEDL, P.S. GHEN, Jr. and F.G. BARTTER : J. Clin. Endocrinol. \& Metab., $20: 515$, (1960). 17) BOOTH, M., P.F. DIXON, G.H. GRAY, J.M. GREENAWAY and N.J. HOLNESS : J. Endocrinol., 23 : 25, (1961).

18) 斎藤正行 : 光電比色計による臨床化学検查, 第 5 版 (1954)，130頁，南山堂。 19）斎藤幸一郎，本田良行：日新医学，42：167，(1955)。 20) Mc LEAN, F.C. and A.B. HASTINGS : J. Biol. Chem., $108: 285$, (1935). 21) EIK-NES, K., J.A. SCHELLMAN, R. LUMRY and L.T. SAMUELS : J. Biol. Chem., $206: 411$, (1954). 22) BONGIOVANNI, A.M. and W.R. EBERLEIN : J. Clin. Endocrinol. \& Metab., $17: 238$, (1957). 23) SCHELlmAN, J.A., R. LUMRY and L.T. SAMUELS : J. Am. Ghem. Soc., 76 : 2808, (1954). 24) CHEN, P.S. Jr., I.H. MILLS and F.C. BARTTER : Fourth International Biochemical Congress, Vienna, (1958). [文献16) より引用] 25) GHEN, P.S. Jr., I.H. MILLS and F.C. BARTTER : J. Endocrinol., $23: 129$, (1961). 26) KLOTZ, I.M., F.M. WALKER and R.B. PIVAN : J. Am. Chem. Soc., 68 : 1486, (1946). 